\title{
Surfactants in droplet-based microfluidics
}

\author{
Jean-Christophe Baret*
}

\begin{abstract}
Surfactants are an essential part of the droplet-based microfluidic technology. They are involved in the stabilization of droplet interfaces, in the biocompatibility of the system and in the process of molecular exchange between droplets. The recent progress in the applications of droplet-based microfluidics have been possible by the development of new molecules and their characterizations. In this paper, the role of the surfactant in droplet-based microfluidics is discussed with an emphasis on the new molecules developed specifically to overcome the limitations of 'standard' surfactants. Emulsion properties and interfacial rheology of surfactantladen layers strongly determine the overall capabilities of the technology. Dynamic properties of droplets, interfaces and emulsions are therefore very important to be characterized, understood and controlled. In this respect, microfluidic systems themselves appear to be very powerful tools for the study of surfactant dynamics at the time- and length- scale relevant to the corresponding microfluidic applications. More generally, microfluidic systems are becoming a new type of experimental platform for the study of the dynamics of interfaces in complex systems.
\end{abstract}

This document is the last author version of the manuscript published as: Surfactants in dropletbased microfluidics, J.-C. Baret, Lab Chip (2012)

https://doi.org/10.1039/C1LC20582 J

*Droplets, Membranes and Interfaces; MPI for Dynamics and Self-organization, Am Fassberg 17, 37077 Goettingen, Germany 


\section{Introduction}

Exactly 10 years ago, in 2001, Todd Thorsen, Richard W. Roberts, Frances H. Arnold and Stephen

R. Quake reported in Physical Review Letters the first use of microfluidic chips for the production of monodisperse droplets ${ }^{1}$ (see Figure 1). At the end of the Letter, the authors stated: 'This system may also find application as a component in a microfluidic screening chip, since it has been shown that subnanoliter vesicles have significant potential as tools for screening of biological and synthetic compounds'. Interestingly, the parallelisation of reactions in small droplets is also thought to have a role in the prebiotic evolution of life ${ }^{2}$ : among the billions of small reservoirs generated at the surface of oceans and stabilized by small amphiphilic molecules, a couple of favorable conditions might have arisen for the early synthesis of short polymers while the dynamics of coalescence and splitting of droplets would represent basic reproduction mechanisms.

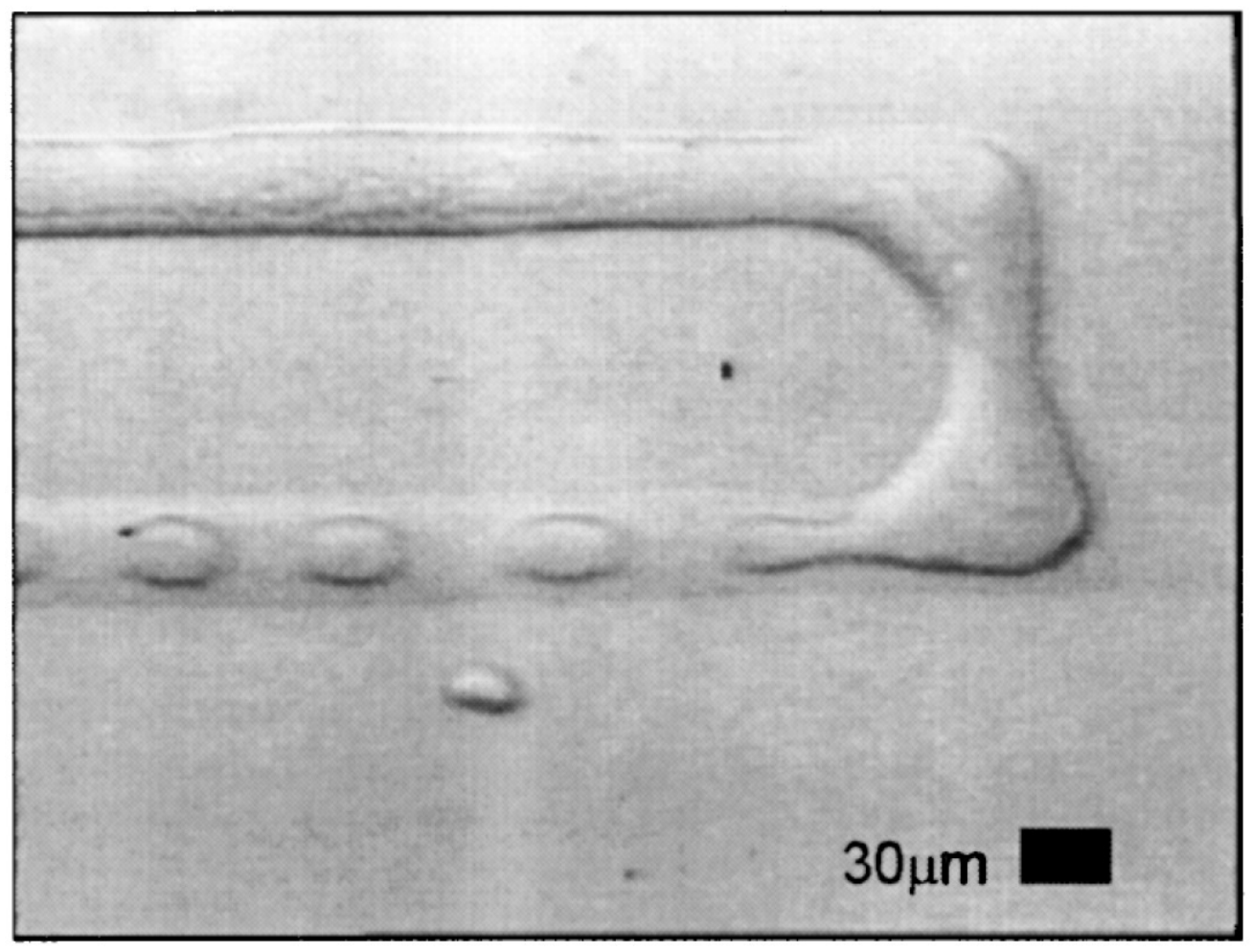

Figure 1 Droplet production in a microfluidic chip. The monodispersity of the droplets makes it appealing for biochemical applications but also as a model tool to understand the physics and physical-chemistry of interfaces. Figure reprinted with permission from Thorsen et al., PRL, 86, 4163, 2001. Copyright (2001) by the American Physical Society ${ }^{1}$ 
Droplet-based microfluidics is now indeed used as a component for many applications in biotechnology. Recent reviews summarize the basics of droplet-based microfluidics and of droplet manipulation techniques ${ }^{3-6}$, as well as the range of applications of the technology ${ }^{7-9}$. To summarize, the interest of the technology lies in the fact that (i) droplets are microreactors of a size perfectly suited for the manipulation of single genes, cells or organisms (typically 1 to $100 \mathrm{mi}-$ crons) and that (ii) these droplets can be manipulated in an automated manner in microfluidic channels at a very high throughput (typically 1000 to 10000 droplet per second).

If it becomes clear that droplet-based microfluidics has a great potential for many applications in biotechnology - some of them will be discussed in the following - questions might arise on the limits of the technology: can this be a universal system for the miniaturization and automation of biochemical assays ? In order to answer this question, the essential characteristics of the system - namely the manipulation of emulsion - has to be considered: understanding how general the approach can be, lies in the understanding and the control of the properties of emulsions.

In the present manuscript, we want to focus on one central ingredient of the droplet-based microfluidic technology: the surfactant. These amphiphilic molecules are commonly used to stabilize the droplet interface and prevent coalescence of droplets. However, their use has some impacts on the feasibility of biochemical assays. In the first section of the manuscript, we will summarize the use of various emulsification systems through the applications they are used for, and the limitations encountered. In the second section of the manuscript, we will review how microfluidic devices are now taylored to study surfactants and emulsions, especially their dynamic behaviors, for a better understanding of the physics of interfaces. 


\section{Surfactants and emulsions}

The term 'surfactant' is the contraction of 'surface active agent' ${ }^{10}$. It describes an amphiphilic molecule, i.e. with different groups having affinities for different immiscible phases (water/air, water/oil, oil/air...). This property drives the molecule to the interface: the surface tension between the two phases is decreased. The decrease of the surface tension is directly given by the amount of molecules adsorbed at the interface as given by the Gibbs adsorption isotherm for dilute solutions $^{11}$ :

$$
\Gamma=-\frac{c}{R T} \frac{\mathrm{d} \gamma}{\mathrm{d} c}
$$

where $\Gamma$ is the surface concentration, $c$ the surfactant bulk concentration and $\gamma$ the surface tension ( $T$ is temperature and $R$ the gas constant). Other properties of the interface (flow, interactions...) are also modified by surfactant as seen in the simple experiment of rising bubble ${ }^{12}$. In the presence of surfactant (for example a protein), after a transient decay the speed of the bubble rising in the protein solution stabilises to a value smaller than in the pure water case. As surfactant adsorbs to the interface, the interface rigidifies: the loss of mobility imposes a change in the boundary condition at the bubble interface which slows it down ${ }^{12}$. In the viscous case, the drag force on the droplet is intermediate between those of a solid or a gas body ${ }^{13}$. The origin of the rigidification is the so-called Marangoni effect: as the bubble moves, the surfactant distribution is non-uniform, with an excess at the rear of the bubble. The non-uniform surface concentration leads to a gradient in surface tension (the surface tension is decreased at the rear of the bubble) which generate a stress opposed to the flow (Figure $2(\mathrm{a}, \mathrm{b})$ ). Interestingly, this Marangoni force already rigidifies the interface when the surfactant concentration at the interfaces is less than half the equilibrium concentration $^{12}$. The motion of surfactant at the interface, its exchange properties with the bulk phase, and the response of surfactant layers to deformations of the interface are dynamic processes controlling the rheological properties of the interface: surfactants modify not only the behavior of interfaces but also the behavior of the whole liquid structure through the coupling with the flow around the interface ${ }^{14}$. 
In emulsions ${ }^{15}$, surfactants have a basic role: they guarantee that droplets do not coalesce, which is the minimal requirement for the use of droplets as microreactors. The dispersion of a fluid into another is a system out of thermodynamic equilibrium: the total energetical cost for the formation of the interfacial area is defavorable and the minimum of energy of the system is a configuration where the two liquids are separated in two phases. The driving force acting towards the homogeneisation of the system is balanced by the action of surfactants. Adding surfactants provides an energy barrier to stabilize the dispersion in a metastable state ${ }^{15,16}$. Dynamic processes are then controlling the stability of the emulsion. One aging mechanism of emulsions is induced by coalescence of droplets. Surfactants hinder such process through two (not mutually exclusive) mechanisms: (i) droplet are stabilized by steric repulsion of the surfactant molecules as in colloidal dispersions and (ii) surfactant gradients at the droplet interface induced by the drainage of the continuous film between two droplets will result in a force acting against the drainage, according to the previously discussed Marangoni effect ${ }^{17}$ (Figure $2(\mathrm{c}, \mathrm{d})$ ).

Besides the coalescence mechanism, Ostwald ripening ${ }^{15,18}$ is another aging mechanisms: small droplets of the emulsion having a higher Laplace pressure than larger droplets, they will then tend to dissolve in the larger ones leading to an increase of droplet size in time and coarsening of the emulsion. This is possible when the dispersed phase is even slightly soluble in the continuous phase. This effect can be reduced by adding to the droplet species that are not soluble in the continuous phase. A loss of the dispersed phase in the small droplets leads to an increase of osmotic pressure that hinders the exchange of the dispersed phase. These osmotic effects can lead to a polydisperse emulsion with well defined droplet sizes ${ }^{19}$. Finally, in other cases, the solute of the dispersed phase can be exchanged by phase partitioning, either directly in the continuous phase or in the surfactant micelles of the continuous phase ${ }^{19-21}$. In all these cases, the surfactant plays a key role in these mechanisms as depicted in the case of oil-in-water emulsion in Figure $3^{22}$. 


\section{(a)}

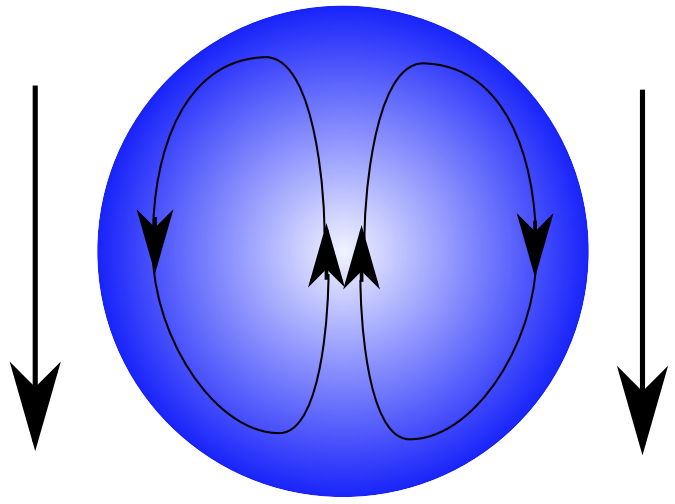

(c)

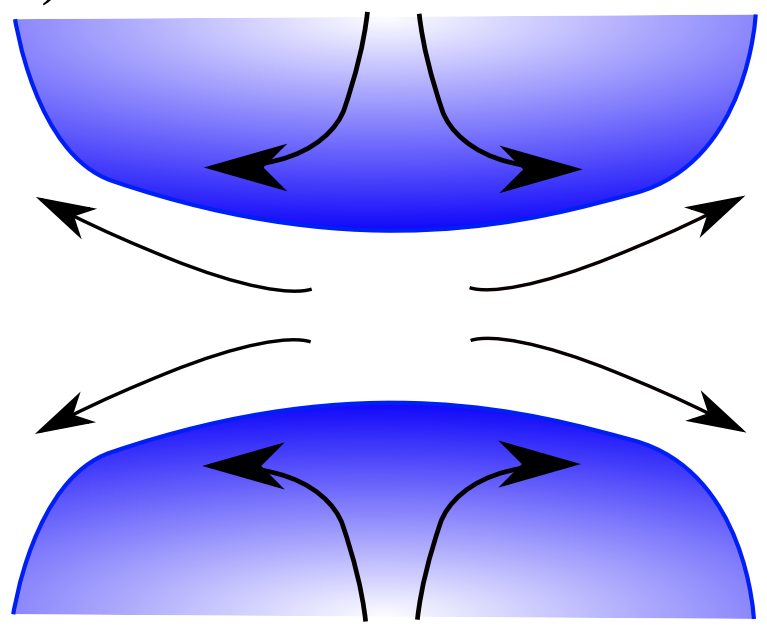

(b)

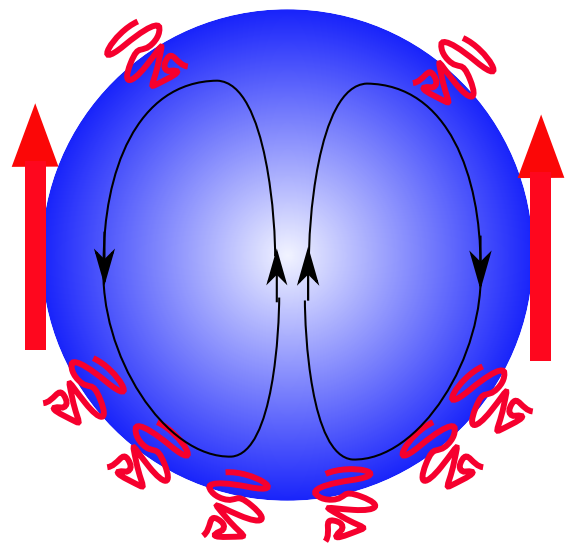

(d)

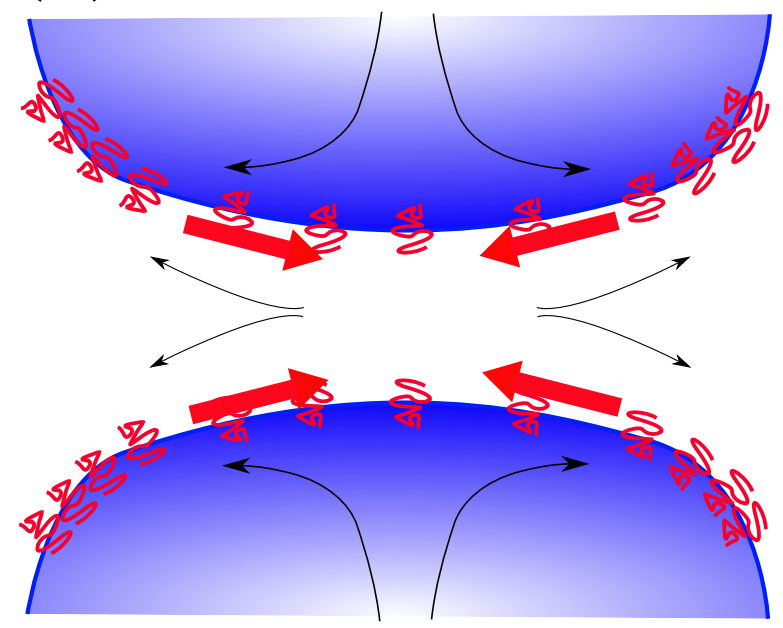

Figure 2 Marangoni effects in the presence of surfactant. (a) The flow pattern in the absence of surfactant for a droplet moving in a surrounding fluid is given by the black arrows (in the reference frame of the droplet). (b) in the presence of surfactant, the flow induces a heterogeneous surfactant distribution causing a Marangoni stress opposing to the flow (red arrow): the viscous drag is then modified by the presence of surfactant which rigidifies the interface. (c) Upon collision of droplets, the continuous phase has to be drained before droplets coalesce. (d) in the presence of surfactants, the gradient of surface density of the surfactant generates a Marangoni stress (red arrows) which counteracts the film drainage, increasing this drainage time ${ }^{17}$ and therefore stabilising the emulsion against coalescence.

\section{Microreactors for biochemical reactions}

The parallelisation and automation of liquid handling in droplet-based microfluidics makes it appealing for many biotechnology applications. The droplets can be produced on chip using various mechanisms ${ }^{1,23,24}$, splitted to increase production rates ${ }^{25,26}$, reinjected $^{27}$, incubated ${ }^{28,29}$, fused $^{24,30,31}$, analyzed and sorted ${ }^{27,32-34}$. The parallelisation of the reactions in the droplets has the 


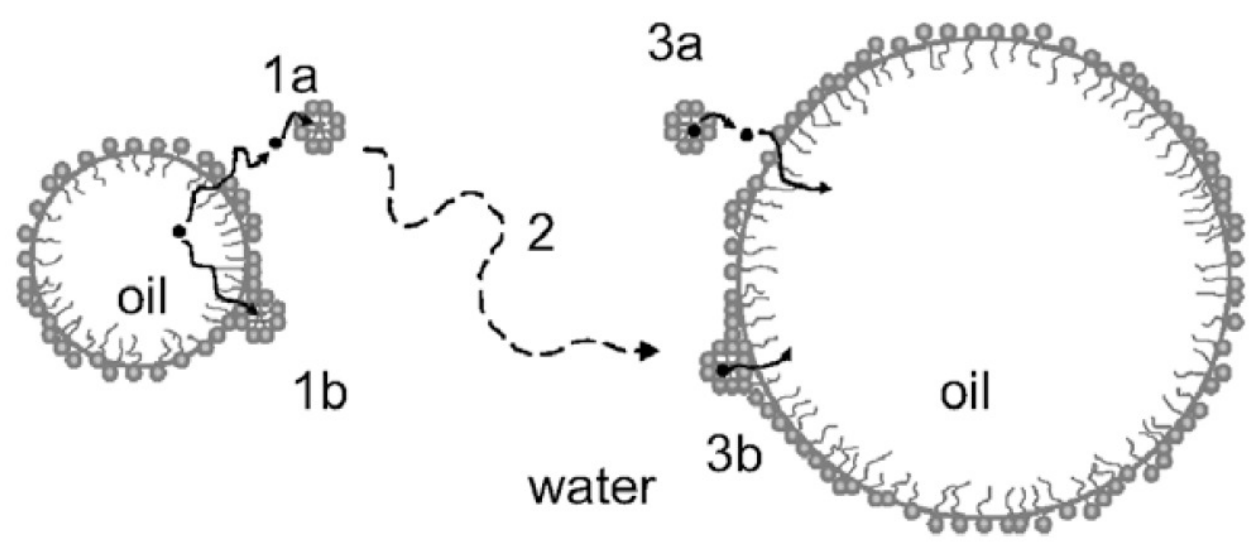

Figure 3 Role of surfactant micelles in the transport between droplets in the case of Ostwald ripening ${ }^{22}$. Oil molecules solubilised in micelles (1a,1b) diffuse through the oil (2) and are uptaken by another droplet (3a, 3b). Reprinted from J. Colloid Interface Sci, Ariyaprakai and Dungan, 343, 102 (2010), Copyright (2010), with permission from Elsevier ${ }^{22}$.

advantage that different reactions can proceed in different droplets: different chemicals or, alternatively, one single compound at different concentrations, can be screened ${ }^{35-37}$ providing automated tools for optimizing chemical synthesis. For example, droplet-based microfluidics provides tools to obtain informations at the single cell level and on large populations which is extremely powerful as an analytical tool to find extraordinary variants or obtain statistically relevant data ${ }^{36,37}$. Millions of different gene variants can be encapsulated in droplet and individually amplified for quantitative emulsion PCR ${ }^{38-40}$. At the single gene level, such systems are especially interesting for diagnostics, in order to find mutants of genes among a large population of normal genes ${ }^{41-43}$. Finally, by enabling the selection of specific variants in a population, successive rounds of mutagenesis and selection can be performed in an automated manner and on small volume for directed evolution of enzymes or micro-organisms ${ }^{27,34}$.

For these biochemical applications, the surfactant - and, in general, the emulsification system (i.e. the combination of oil phase, aqueous phase and surfactant) - must be biocompatible. The oil-water interface must appear as inert as possible to the droplet content. Indeed with the miniatur- 
ization of the assay in micrometer-sized droplets, interfacial effects become predominant compared to bulk and the downscaling of the assay can only be achieved with a minimisation of the surface effects. Biocompatibility can basically be summarized as the fact that the bio-chemical reaction performed in droplets must be as efficient as in bulk. The best examples of non-biocompatible systems are given by the adsorption or the denaturation of proteins at the water / oil interface ${ }^{44}$ (Figure 4) or the interactions of surfactants with cell membranes or proteins ${ }^{45}$. In order to use

a)

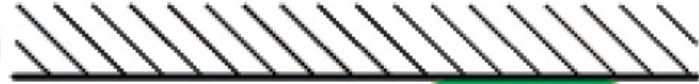
$\mathrm{R}_{\mathbf{f}}-\mathrm{CH}_{2} \mathrm{CH}_{2} \mathrm{OH}$ FC
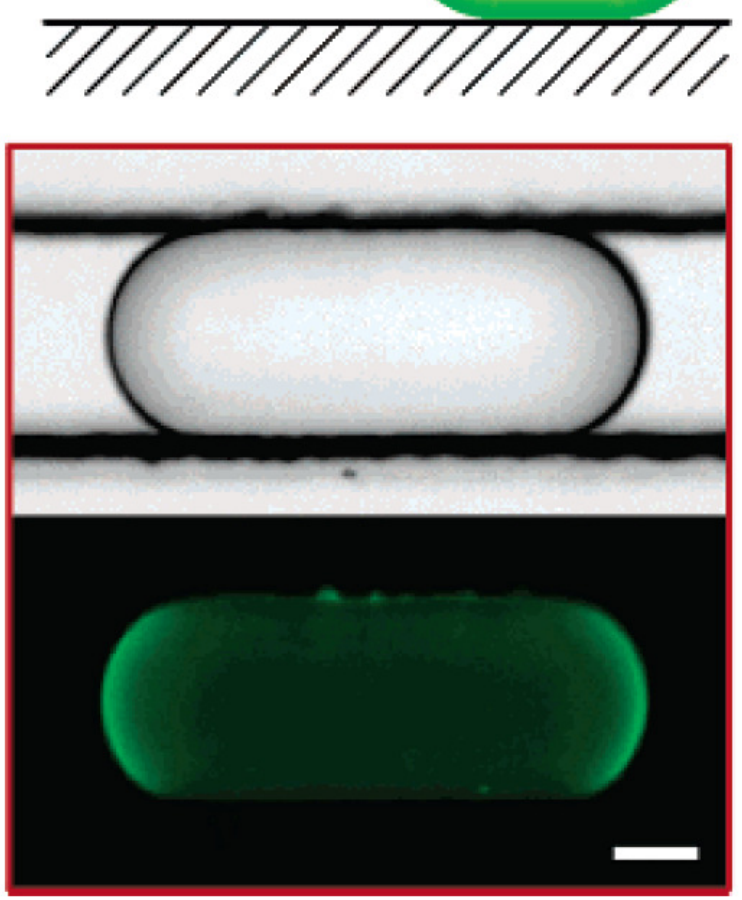

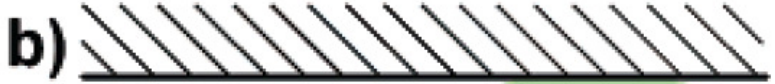

$\mathrm{R}_{\mathbf{f}}$-OEG $+$

FC

AlexaFluorfibrinogen
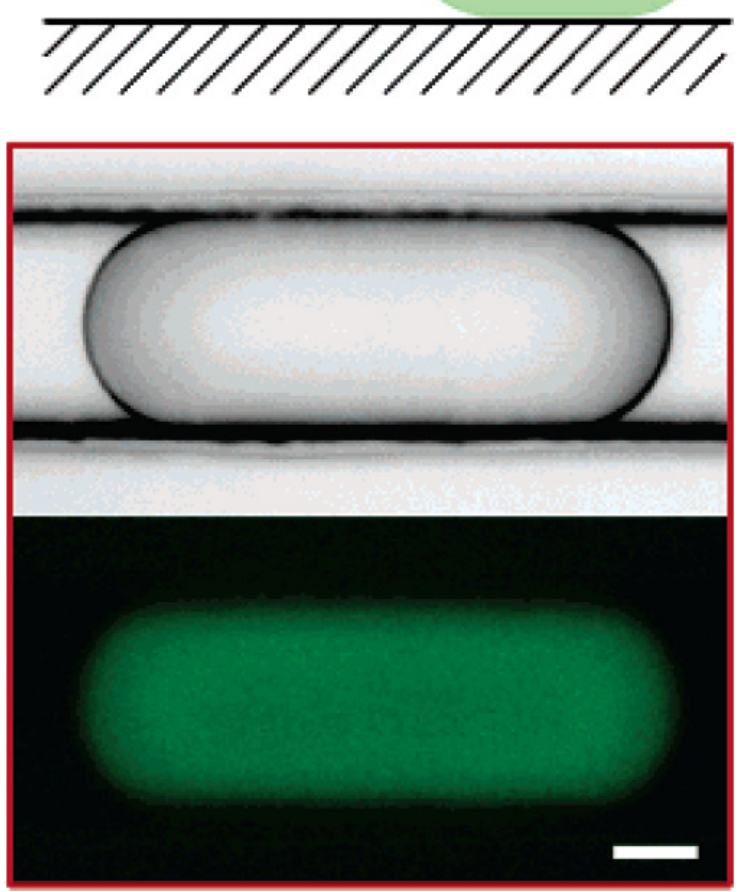

Figure 4 Protein adsorption in droplets as a function of the polar head group of the surfactant. (a) adsorption of fibrinogen at the interface with an alcool head group. (b) Polyethylenoxide head groups reduce protein adsorption as revealed by the distribution of fluorescence at the droplet-oil interface. Reprinted with permission from Roach et al., Anal. Chem., 77, 785 (2005). Copyright (2005) American Chemical Society ${ }^{44}$.

droplets as microreactors, these three major points - stability (Figure 2), control of exchange (Figure 3) and biocompatibility (Figure 4)- have to be addressed at the same time which gives a very 
stringent constraint on the surfactant and the emulsification system to be used.

Although many emulsification systems have been described and are commercially available, only a few have been successfully used for biochemical applications in microfluidics. One of the original application for emulsion is amplification of DNA in droplets (emulsion PCR) used as a sample preparation for DNA sequencing. In this case, single genes are encapsulated and amplified in parallel within the emulsion. One advantage that microfluidics brings to PCR from single genes is the monodispersity of the droplet microreactors: it ensures that each single DNA fragment is encapsulated in a reservoir identical to the other. The monodispersity of the emulsion is then a key for quantitative amplification from single genes. PCR is a very good example of the constraints on the emulsification system since the multiple cycles of temperature up to 95 degrees are a very strong constraint on the system. The interfacial activity and the physical-chemical parameters of the surfactant such as the critical micellar concentration are a function of the temperature and obtaining a stable system over a wide range of temperature is difficult. A recent review summarizes the efforts and progress in the field ${ }^{46}$. Emulsion PCR has been originally reported in silicone oils (Table 1) in non-microfluidic systems ${ }^{47}$ and later in microfluidics ${ }^{48,49}$ where the poor compatibility of silicone oils with microfluidic chips produced in $\mathrm{PDMS}^{50}$ requires the use of glass devices $48,49,51$. Alternative systems are based on hydrocarbon oils which have been successfully used for PCR applications ${ }^{52,53}$ (Table 2) and for directed evolution of enzymes ${ }^{54}$. However in hydrocarbon systems, hydrophobic compounds can phase partition into the oil which limits the range of applications ${ }^{55}$. With a leaking microreactor, bio-chemical assays can only be performed provided that the exchange of molecules is not a limiting step. They are therefore limited to the applications such as PCR where the objects of interest (the DNA or RNA fragments) do not exchange between the droplets. Finally, fluorinated oils and fluorosurfactants are also suitable for single gene amplification ${ }^{41-43,56}$. The droplets can be thermocycled on chip ${ }^{56}$ or off-chip ${ }^{41-43}$ and further reinjected in other microfluidic chips for analysis. Figure 5 shows the example of an emulsion plated after a PCR amplification with Taqman probes for the detection of mutant genes 
in a pool of normal genes ${ }^{42}$.
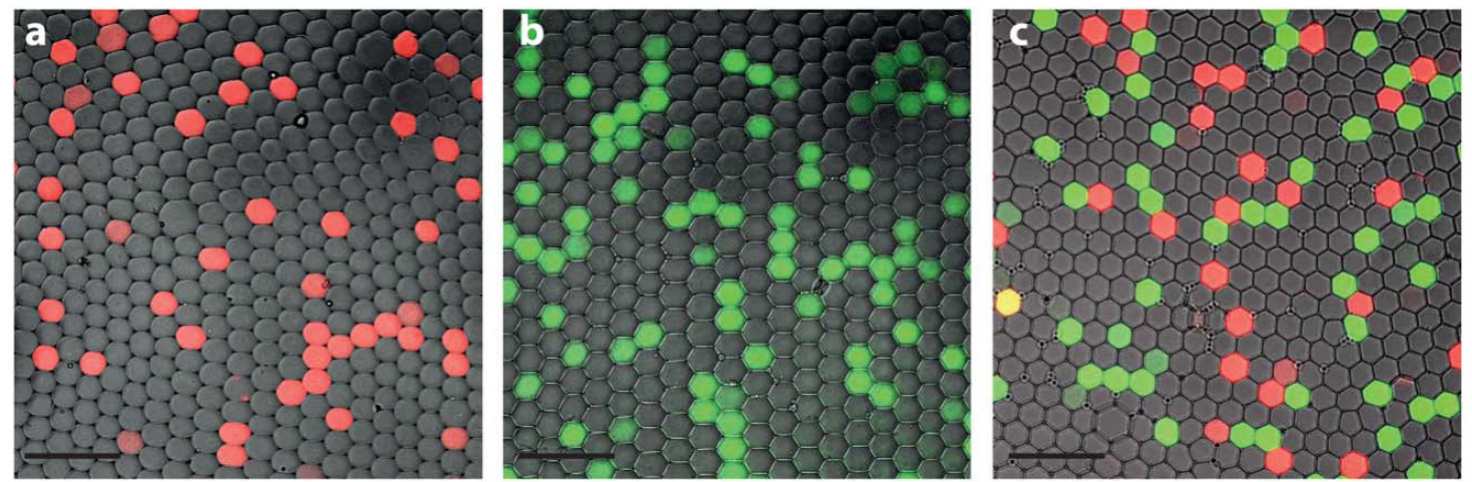

Figure 5 Water in fluorinated oil emulsion after thermocycling for PCR. The droplet color indicates the presence of a normal gene in the droplet ( $\mathrm{a}$ - red) or mutant ( $\mathrm{b}$ - green) using Taqman probe. The ratio of green droplets to red droplets (c) gives a measurement of the ratio of Mutant to Wild-type gene in a population. This system used for diagnostic relies on the possibility to perform billions of reaction in parallel in droplets for analysis at the single gene level. Pekin et al., Lab Chip, 11, 2156 (2011) Reproduced by permission of The Royal Society of Chemistry ${ }^{42}$ 
Table 1 Reported surfactants (all commercially available) and corresponding applications for water-in-silicon oil emulsions in microfluidics.

\begin{tabular}{|c|c|c|c|}
\hline \multirow[t]{2}{*}{ Surfactant } & \multicolumn{3}{|c|}{ Silicon Oil } \\
\hline & DC200 & PDMS & AR20 \\
\hline Triton X-100 & & & 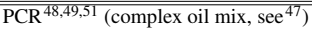 \\
\hline SDS (in water) & & Oil-in-water emulsification ${ }^{57}$ & \\
\hline ABIL EM90 & & & Directed evolution ${ }^{54}$ \\
\hline No surfactant & $\begin{array}{l}\text { Chemical compound storage }{ }^{58} \\
\text { Emulsification }^{60}\end{array}$ & Raman measurement ${ }^{59}$ & \\
\hline
\end{tabular}


Table 2 Reported surfactants (all commercially available) and corresponding applications for water-in-hydrocarbon oil emulsions in microfluidics.

\begin{tabular}{|c|c|c|c|c|c|}
\hline \multirow[t]{2}{*}{ Surfactant } & \multicolumn{5}{|c|}{ Hydrocarbon Oil } \\
\hline & Hexadecane & Tetra/Octa/Dodecane & Mineral oil & Isopar M & Vegetable / organic \\
\hline \multirow[t]{7}{*}{ Span80 } & Emulsification 1,61 & Emulsification $^{1}$ & Protein expression ${ }^{62}$ & Emulsification $^{63}$ & \\
\hline & Coalescence ${ }^{64,65}$ & Droplet patterns ${ }^{66}$ & Droplet patterns ${ }^{67}$ & Droplet pairing ${ }^{68}$ & \\
\hline & Droplet splitting ${ }^{25,69}$ & $\begin{array}{l}\text { Chemical cou- } \\
\text { pling }\end{array}$ & Molecular exchange 20 & Electrocoalescence ${ }^{63}$ & \\
\hline & Interfacial instabilities $^{71}$ & & Cell encapsulation ${ }^{72,73}$ & & \\
\hline & Laser manipulation ${ }^{74}$ & & Chemical reactions $^{75}$ & & \\
\hline & Electrocoalescence ${ }^{31,76}$ & & $\begin{array}{l}\text { Electricaly-assisted emulsifica- } \\
\text { tion }{ }^{77}\end{array}$ & & \\
\hline & Droplet sorting ${ }^{32}$ & & $\begin{array}{l}\text { Electrowetting in emulsifica- } \\
\text { tion }^{78}\end{array}$ & & \\
\hline Monolein & & & & & $\begin{array}{l}\text { Bilayers } \\
\text { (squalane) }^{79}\end{array}$ \\
\hline Oleic acid & & & Tip streaming ${ }^{80}$ & & \\
\hline Tween $20 / 80$ & $\begin{array}{l}\text { Dynamic surface ten- } \\
\text { sion }^{81} \\
\text { Emulsification }^{61}\end{array}$ & & & & \\
\hline Synperonic PEF & $\begin{array}{l}\text { Dynamic surface ten- } \\
\text { sion }^{82}\end{array}$ & & & & \\
\hline C12E8 & & & Tip streaming ${ }^{83}$ & & \\
\hline SDS & $\begin{array}{l}\text { Dynamic surface ten- } \\
\text { sion }^{82} \\
\text { Emulsification }\end{array}$ & & & & \\
\hline N-butanol & & & Interfacial rheology ${ }^{84}$ & & \\
\hline ABIL EM90 & & & $\begin{array}{l}\text { PCR in droplets } \\
\text { Directed evolution }^{54}\end{array}$ & & \\
\hline Phospholipids & & Lipid bilayers ${ }^{86}$ & & & \\
\hline No surfactant & & & $\begin{array}{l}\text { Droplet hydrodynamics }{ }^{87} \\
\text { PCR in droplets }{ }^{40}\end{array}$ & & $\begin{array}{l}\text { Droplet hydrody- } \\
\text { namics } \\
\text { (sunflower oil) }^{88}\end{array}$ \\
\hline
\end{tabular}


Table 3 Reported surfactants and corresponding applications for water-in-fluorinated oil emulsions in microfluidics. $\left({ }^{*} \mathrm{PF}=\right.$ Perfluoro-, $\mathrm{PFPE}=$ Perfluoropolyether, $\mathrm{TD}=$ tetradecanoic- ${ }^{* *}$ Perfluoro-hexane perfluoro-cyclohexane perfluoro-decaline perfluoro-perhydrophenantren)

\begin{tabular}{|c|c|c|c|c|c|c|c|}
\hline \multirow[t]{2}{*}{ Surfactant $^{*}$} & \multirow[t]{2}{*}{ Source } & \multicolumn{6}{|c|}{ Fluorinated Oil } \\
\hline & & $\begin{array}{l}\mathrm{PFH} / \mathrm{PFC} / \mathrm{PFD} / \\
\mathrm{PFPH}^{* *}\end{array}$ & $\begin{array}{l}\text { Carrier oil (Rain- } \\
\text { dance Technolo- } \\
\text { gies) }\end{array}$ & HFE / Novec & FC40 & FC70 / FC77 & FC3283 \\
\hline PF-octanol & Commercial & $\begin{array}{l}\text { Reaction kinet- } \\
\text { ics } \\
\text { Protein } \\
\text { tion }^{93}\end{array}$ & & & microPIV $^{91}$ & $\begin{array}{l}\text { Compound screen- } \\
\text { ing }{ }^{92} \\
\text { Cell sorting }\end{array}$ & $\begin{array}{l}\text { Protein } \\
\text { tion }{ }^{33}\end{array}$ \\
\hline PF-decanol & Commercial & & & & PCR in droplets ${ }^{94}$ & & \\
\hline PF-TD acid & Commercial & & & & & & $\begin{array}{l}\text { Protein adsorp- } \\
\text { tion }^{44}\end{array}$ \\
\hline PF-TD OEG & $\begin{array}{l}\text { Home made } \\
\text { (from above) }\end{array}$ & & & & & & $\begin{array}{l}\text { Protein adsorp- } \\
\text { tion }^{44} \\
\text { Chemistrode }^{95}\end{array}$ \\
\hline PFPE-COOH & $\begin{array}{l}\text { Commercial } \\
\text { (Krytox, Dupont) }\end{array}$ & & & $\begin{array}{l}\text { Splitting droplets }{ }^{26} \\
\text { Droplet detection }^{97}\end{array}$ & Electrocoalescence ${ }^{96}$ & & \\
\hline $\begin{array}{l}\text { PFPE- } \\
\text { COONH }_{4}\end{array}$ & Home-made & & $\begin{array}{l}\text { Cells } \\
\text { droplets } 36\end{array}$ & Multiple emulsions ${ }^{98}$ & Cells in droplets ${ }^{99}$ & & \\
\hline & $\begin{array}{ll}\text { (from } & \text { Krytox, } \\
\text { Dupont) } & \end{array}$ & & & & $\begin{array}{l}\text { Droplet hydrodynam- } \\
\text { ics } 100\end{array}$ & & \\
\hline & & & & & Chemical reaction ${ }^{101}$ & & \\
\hline PFPE-PEG & Home-made & & $\begin{array}{ll}\text { Cells } & \text { in } \\
\text { droplets }^{36} & \end{array}$ & Directed evolution $^{34}$ & Cells in droplets ${ }^{99}$ & & \\
\hline & $\begin{array}{l}\text { (from Krytox, } \\
\text { Dupont) }\end{array}$ & & & Picoinjector ${ }^{102}$ & Dropspot $^{103}$ & & \\
\hline & EA, Proprietary & & $\mathrm{PCR}^{56}$ & PCR and diagnostics ${ }^{42}$ & Coalescence ${ }^{104}$ & $\begin{array}{l}\text { Molecular } \\
\text { change }^{20}\end{array}$ & \\
\hline & (Raindance Tech.) & & Diagnostics $^{43}$ & DNA amplification ${ }^{105}$ & $\begin{array}{l}\text { Chemical gradi- } \\
\text { ents }{ }^{106}\end{array}$ & $\begin{array}{l}\text { Chemical } \\
\text { ents } 106\end{array}$ & \\
\hline & & & & $\begin{array}{ll}\begin{array}{l}\text { Sorting } \\
\text { organisms }^{27,107}\end{array} & \text { micro- }\end{array}$ & Droplet separation 108 & & \\
\hline & & & & Yeasts in droplets ${ }^{19}$ & Electrocoalescence ${ }^{96}$ & & \\
\hline PFPE-DMP & Home-made & & & Cells in droplets ${ }^{99,109}$ & $\begin{array}{l}\text { Bacteria } \\
\text { droplets }^{110}\end{array}$ & & \\
\hline & $\begin{array}{l}\text { (from Krytox, } \\
\text { Dupont) }\end{array}$ & & & Coalescence $^{111}$ & & & \\
\hline Short chains & $\begin{array}{l}\text { Home-made } \\
\text { synthesis }\end{array}$ & & & & & & $\begin{array}{l}\text { Surface tension } \\
\text { and emulsifica- } \\
\text { tion }{ }^{112,113}\end{array}$ \\
\hline No surfactant & & & & Bacteria / antibiotics ${ }^{114}$ & & & \\
\hline
\end{tabular}


Many other applications of droplet-based microfluidics rely on the use of fluorinated oils and fluorosurfactants (Table 3). The choice of fluorinated oils is mainly driven by two points: first, they are appealing since most of organic compounds are insoluble in these oils. The compounds encapsulated in the droplet should not phase partition and therefore remain in the droplet which solves the exchange limitations of organic and silicone oils. The second advantage of fluorinated oils is biocompatibily. The first experiments showing the growth of cells on fluorocarbon liquid interfaces dates back to the 80 's ${ }^{115}$. These oils are compatible with cell culture but the importance of surfactants on the cell growth has been reported ${ }^{116,117}$. The cell spreading on the surface is linked to the ability of the cells to grow on a protein film at the oil interface (Figure 6). At the same

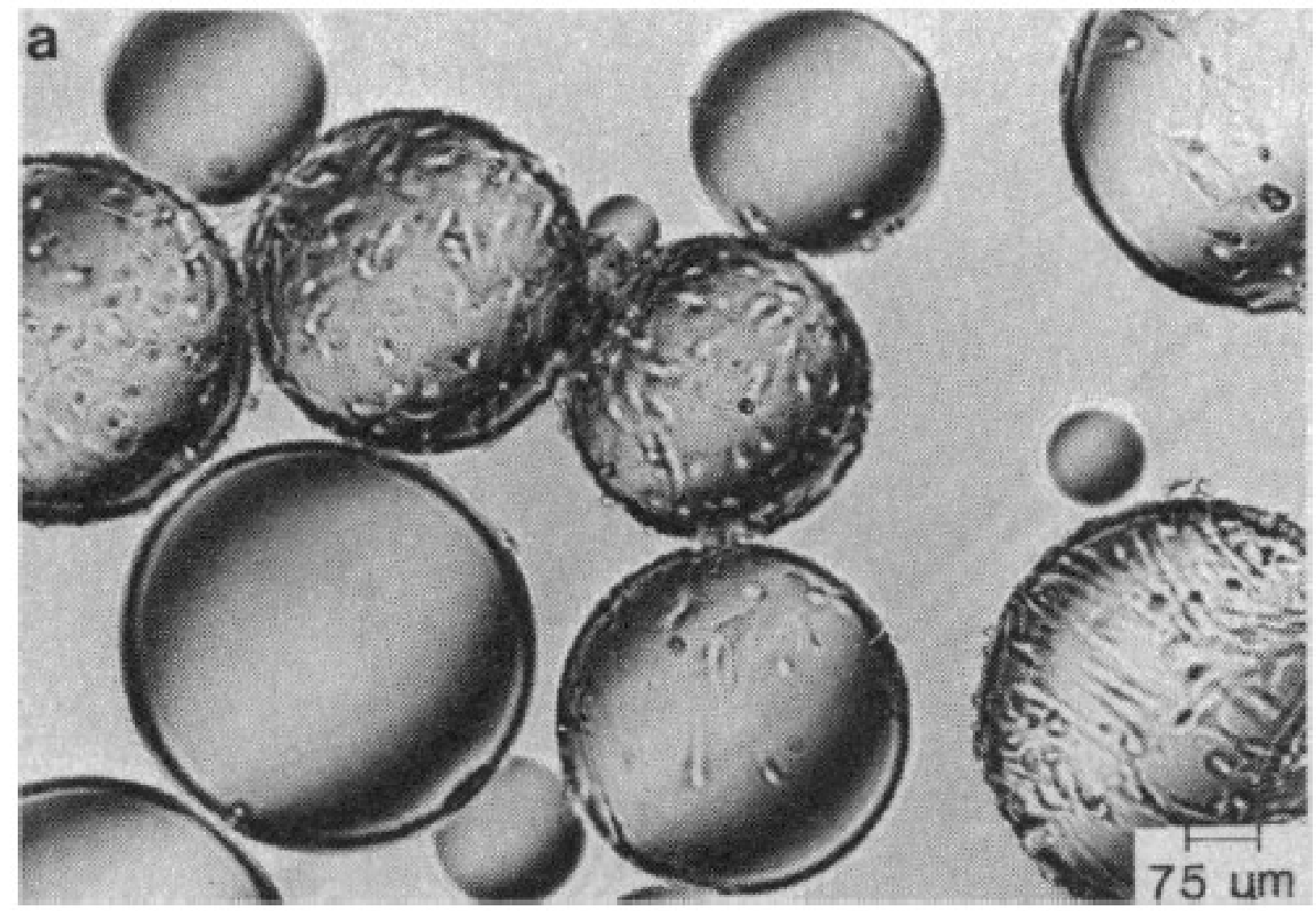

Figure 6 Example of cell growth on polylysine coated droplet of fluorinated oil (FC-70) . The cells adhere well at the droplet surface and show the same division rate as in conventional cell culture ${ }^{116}$. Figure from Keese and Giaver, Science, 219, 1448 (1983). Reprinted with permission from AAAS. ${ }^{116}$

time, the capabilities of fluorinated oils to solubilise gases ${ }^{118}$ is a key for cell survival. Systems 
based on fluorocarbon oils are used in clinical tests as artificial blood substitutes, mostly for their interesting properties regarding gas exchange ${ }^{119-122}$. A microfluidic example of the use of the high solubility of respiratory gases in fluorinated oils is given in Abbyab et al. ${ }^{109,123}$. When red blood cells have a genetic mutation leading to polymerization of hemoglobin fibers upon release of oxygen (as in the case in sickle cell anemia), those cell undergo a morphological transition. The authors used droplets to encapsulate red blood cells and a fluorinated oil as oxygen carrier. They observed the morphological transition of the sickle cells as a function of the oxygen content in the oil phase (Figure 7). Several rounds of oxygenation and deoxygenation of the cells could then be performed in order to reproduce the cycles red blood cells would undergo during respiratory cycles in the human body.

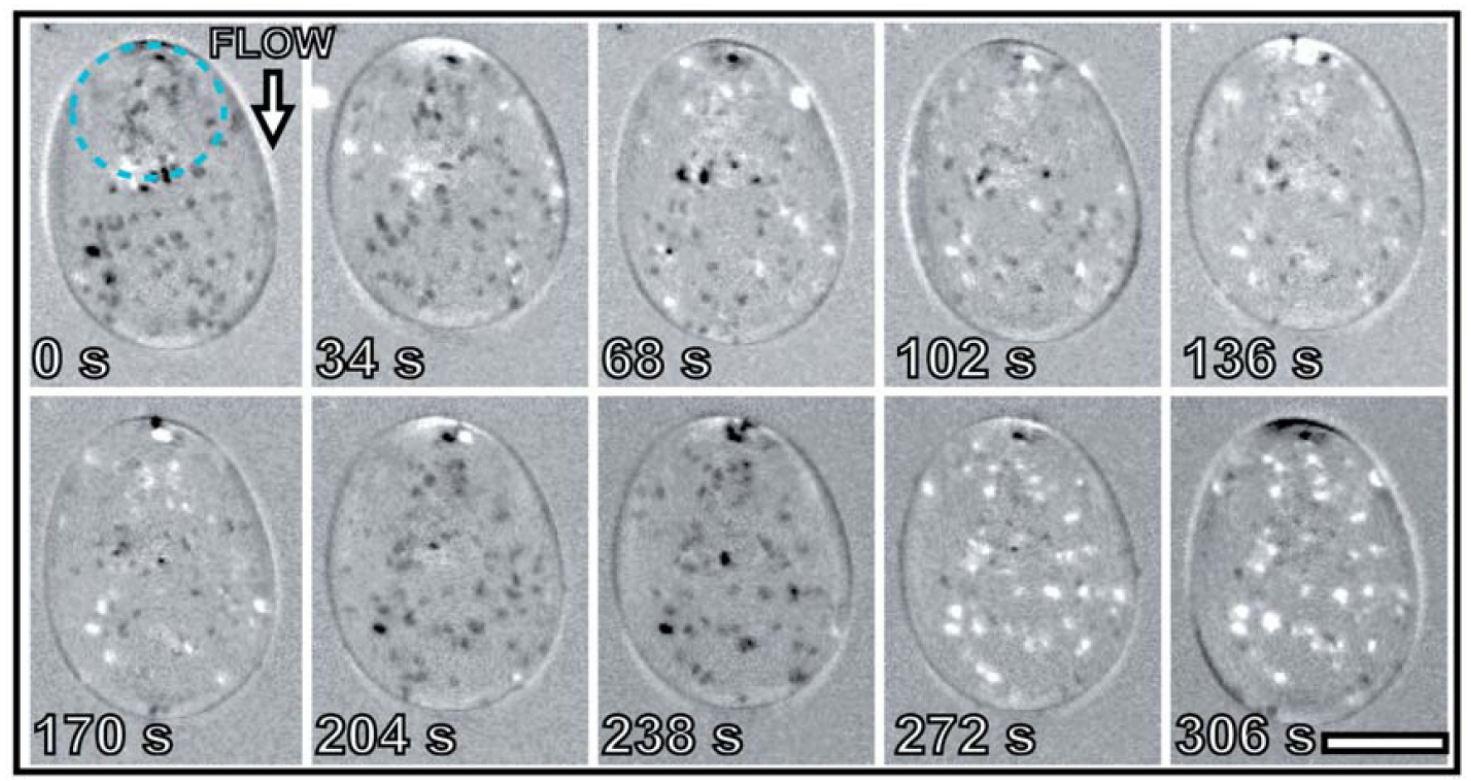

Figure 7 Water in fluorinated oil emulsion for the control of the oxygenation of red blood cells. The cells appear as black dots in their native state and as white dots when hemoglobin fiber polymerize (as in the case of sickle cell anemia). By controlling the amount of oxygen in the oil as a function of time, several cycles of oxygenation - deoxygenation of the cells are performed, mimicking the cycles the cells would undergo in the human body ${ }^{109,123}$. Abbyad et al., Lab Chip, 11, 813 (2011)-Reproduced by permission of The Royal Society of Chemistry ${ }^{123}$ 


\section{Biocompatible surfactants}

Although fluorinated oils represent a very promising component in the system, the range of surfactants available for the stabilization of water in oil interfaces is still limited. Fluorosurfactants (Perfluoropolyethers - PFPE - with hydrophilic head groups) are used as emulsifiers for supercritical $\mathrm{CO}_{2}{ }^{124}$ and are perfectly suited to stabilize water in fluorinated oil emulsions. Although the carboxylic terminated PFPE has questionnable biocompatibility properties ${ }^{125}$, many other fluorinated surfactants have been reported to show very interesting biocompatibility properties ${ }^{126}$. For example some fluorinated surfactants with short fluorinated tails are used as therapeutic agents in lung deficiencies cases or for carrier of drugs through the pulmonary route ${ }^{127,128}$. Surfactants with short fluorinated tails have been used in microfluidic systems: perfluorooctanol (PFO) was, for example, used for the study of chemical reactions and protein cristallisation ${ }^{89,93}$. However, the system showed some limitations in terms of biocompatibility, for example, non-specific interaction of the surfactant with fibrinogen ${ }^{44}$. Using various head groups on the short fluorinated chain of PFO, it has also been shown that the biocompatibility (measured through protein adsorption at interfaces) is directly linked to the chemistry of the hydrophilic head group ${ }^{44}$. Chemical modifications of the head of the surfactant lead to an increase of protein adsorption for a carboxylic head-group or to a decrease of adsorption (enhanced biocompatibility) with a short ethylenoxide chain $^{44}$ (Figure 4).

Over the past years, other molecules have been developed specifically for their use in microfluidic applications. Amphiphilic molecules with perfluoropolyether chains or perfluoroalkyl chains and hydrophilic head groups have been reported ${ }^{99,112,113,129,130}$. Currently, the most promising molecules consist in a block copolymer of perfluoropolyether and polyethylenoxide. These block copolymers reduce protein adsorption or the interactions with cell membranes. Such molecules have been used to screen mammalian cells, yeasts, bacteria, viruses or for the encapsulation of hybridoma cells 27,34,36,37,99,103,107,131 (Figure 8). Mineral oils have been used with cells, for example focusing on encapsulation mechanisms ${ }^{72,73}$, and also as double-emulsification system to screen bacteria $^{132}$ with incubation times of a few minutes and limited to $\sim 2$ hours ${ }^{132}$. Fluorinated oils 
are - to date - the only examples where cell survival and proliferation has been demonstrated with long-term incubation of organisms where gas exchange becomes crucial ${ }^{99,103}$.

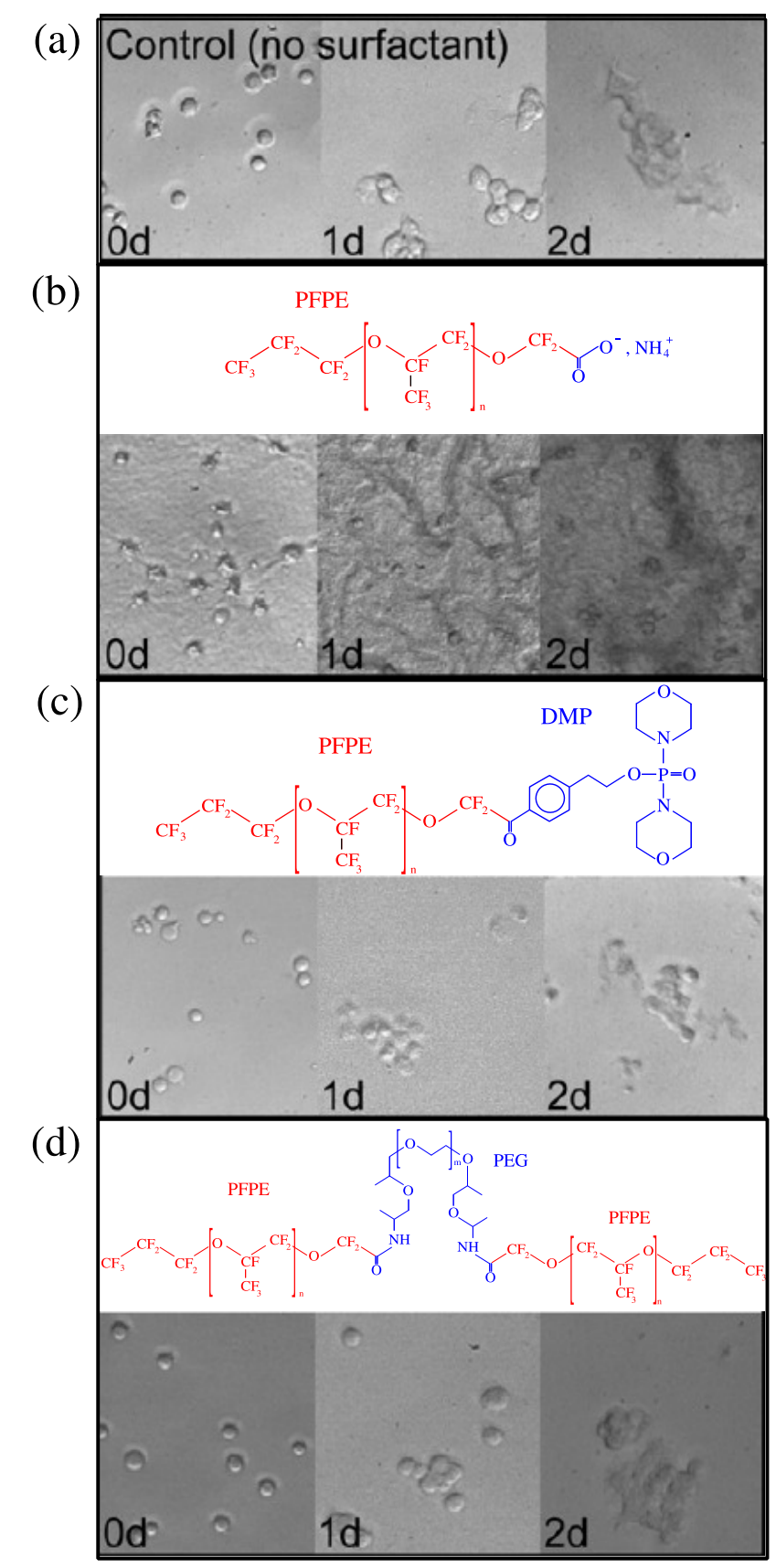

Figure 8 Example of cell growth on surfactant layers using fluorinated oil and fluorosurfactant generated from the same PFPE chain (red) after deposition (0d), after 1 day of incubation (1d) and after 2 days (2d). Polyethylenoxide head groups and dimorpholinophosphate groups are shown to be biocompatible: (c) and (d) show the same behavior as the control without surfactant (a). Polylysine head group (not shown here) or carboxylic head groups (b) was shown to kill cells ${ }^{99}$. Adapted from Chemistry and Biology, Clausell-Tormos et al. 15, 427 (2008), Copyright (2008), with permission from Elsevier. ${ }^{99}$ 


\section{Molecular exchange between droplets}

Adding surfactant to the oil-water system has another consequence. Although the exchange of molecules through phase partitioning is reduced by the use of fluorinated oils, surfactant have an effect on this process. Surfactant bilayers can form between droplet and those can be porous to certain molecules, especially small molecules, as observed during thermocycling ${ }^{55}$. More recently, it has also been shown that the formation of a lipid bilayer between droplets is required to obtain synchronization of droplet assemblies in which an oscillating reaction is taking place ${ }^{70,79}$ : transport through bilayers is therefore an important point to consider. It is however not the only mechanism - besides simple phase partitioning - since it has been shown that micelles solubilised in the continuous phase can act as carrier for small molecules ${ }^{133,134}$. This transport mechanism is function of the lipophobicity of the molecules to be transported, as demonstrated in the case of a mineral oil and non-ionic surfactant (polyoxyethylen oleyl ester) ${ }^{135}$.

In water in perfluorinated oil, it has been demonstrated recently that the exchange rate is a function of the hydrophobicity of the molecules: small fluorescent molecules (coumarine) were used as a model for the exchange: by grafting sulfonate groups on the coumarine, the exchange rate has been drastically reduced ${ }^{136}$. The size of the molecule is also a key point to consider, as demonstrated in numerical models: larger molecules have to overcome a higher energetic barrier to be transported through the surfactant layer ${ }^{21}$. Other mechanisms of exchange have been reported in microemulsions with the possible coalescence and subsequent division of droplets ${ }^{137}$. However, in the case of microfluidic emulsion, this process can be ruled out at the droplet level (such process would lead quickly to a polydisperse emulsion), but might still happen at the micelles level. Solvent is also transported between droplets containing different concentrations of non diffusive compounds. This phenomenon has been observed with yeast cells metabolising sugar in droplets during their growth phase. In order to maintain the chemical potential of the sugar constant, the droplet containing yeast shrinks in order to increase the concentration of remaining sugar ${ }^{19}$. Since water is in this experiment insoluble in the fluorinated oil, the exchange is here again mainly mediated by the micelles and driven by the osmotic pressure difference between the droplets. It is 
therefore important to understand and control such processes in order to guarantee that the microreactors remain intact. Alternatively, one can make use of such transport properties for the control of reactions ${ }^{20,138}$. 


\section{Studying emulsions and surfactants in microfluidics}

Surfactants play a ubiquitous role in droplet-based microfluidic technology. It is therefore important to understand the behavior of these molecules at the time-scale and at the length-scale at which they are used. New characterizations approaches for surfactant and emulsion sciences are required to complement the existing methods and microfluidic systems provide an interesting platform for such studies.

\section{Emulsion stability and surfactant dynamics}

The water in oil emulsions should of course be stable for times sufficiently long to perform the bio-chemical operations. If surfactant free systems might even be usable $40,88,139-141$ surfactants are required for long-term stability, for example, for storage applications. The stability of the reactors is also a very stringent conditions for PCR applications where cycles of temperature have to reach 95 degrees. Long term stability of fluorinated emulsions ${ }^{142}$ have already been reported which, again, makes them an appealing system. It is important to understand the stability of droplet, for example when they flow in microchannels and experience high shear rates. Microfluidic systems are perfectly suited for this type of study because they work exactly at the length and time-scale at which these effects should be studied. The interest of microfluidics for the study of interfaces can be highlighted by the simple problem of the kinetics of surfactant adsorption to interfaces ${ }^{143}$. In standard emulsification systems or in flow focusing geometries, the time scale at which new interfaces are produced is typically in the range of the millisecond or below. However, there is a very limited number of experimental methods that can address the dynamics of surfactant at time-

scales close to the millisecond ${ }^{144}$. Therefore microfluidic systems themselves are now developed towards a better understanding of the basic principles of the physics of interfaces at these short time-scale.

In parallel, the question of the length-scale is relevant. It has indeed been shown that the kinetics of surfactant adsorption is controlled by different processes at large or small scale. The 
kinetics of adsorption involves two processes, (i) diffusion to the interface and (ii) binding to the interface, each of them with a typical time- and length-scale. Above a critical droplet size, surfactant adsorption is controlled by diffusive processes, while below, the process is controlled by the adsorption/desorption kinetics ${ }^{145}$. For classical surfactants, a crossover is found around 20 to 70 microns droplet size. Hence, understanding surfactant kinetics at the right time and length-scale is important. Microfluidics provides a very powerful platform to create and control interfaces, to visualize them, as well as to place these interfaces in external fields (thermal gradients, electric fields, external flow fields...). New experimental approaches are now developed for a better understanding of the physical-chemistry of interfaces.

\section{Coalescence and electrocoalescence}

Understanding coalescence of droplets - with or without surfactants - has been extensively studied. Two approaching droplets merge when the thin oil film drained between them becomes unstable ${ }^{17,146}:$ the coalescence is controlled by the capillary number ${ }^{17,147}$ and adding surfactant delays the coalescence process ${ }^{17}$. Recent studies demonstrated that the instability of the film can be triggered by the forcing of droplet separation ${ }^{64,148,149}$. This process leads to cascades of coalescence in a line of droplets and is the source of massive destabilization of emulsions, even in the presence of surfactant ${ }^{64}$ (Figure 9). Interestingly, these microfluidic experiments bring additional quantitative insights into the physics of emulsions. The cascade of coalescence observed in the microfluidic systems could be a mechanism leading to phase inversion in emulsification which is still an open problem $^{65}$.

The kinetics of surfactant adsorption has also an influence on coalescence. Indeed at the timescale of droplet production (typically $\sim \mathrm{ms}$ ), the surfactant does not fully cover the interface. Therefore droplets colliding right after production have a higher chance to coalescence than if the surfactant has been given time to adsorb at the interface ${ }^{111}$ : microfluidic systems provide

means to study such processes by decoupling droplet production and droplet collisions showing the importance of surfactant adsorption kinetics on the coalescence in emulsions. For applications, 

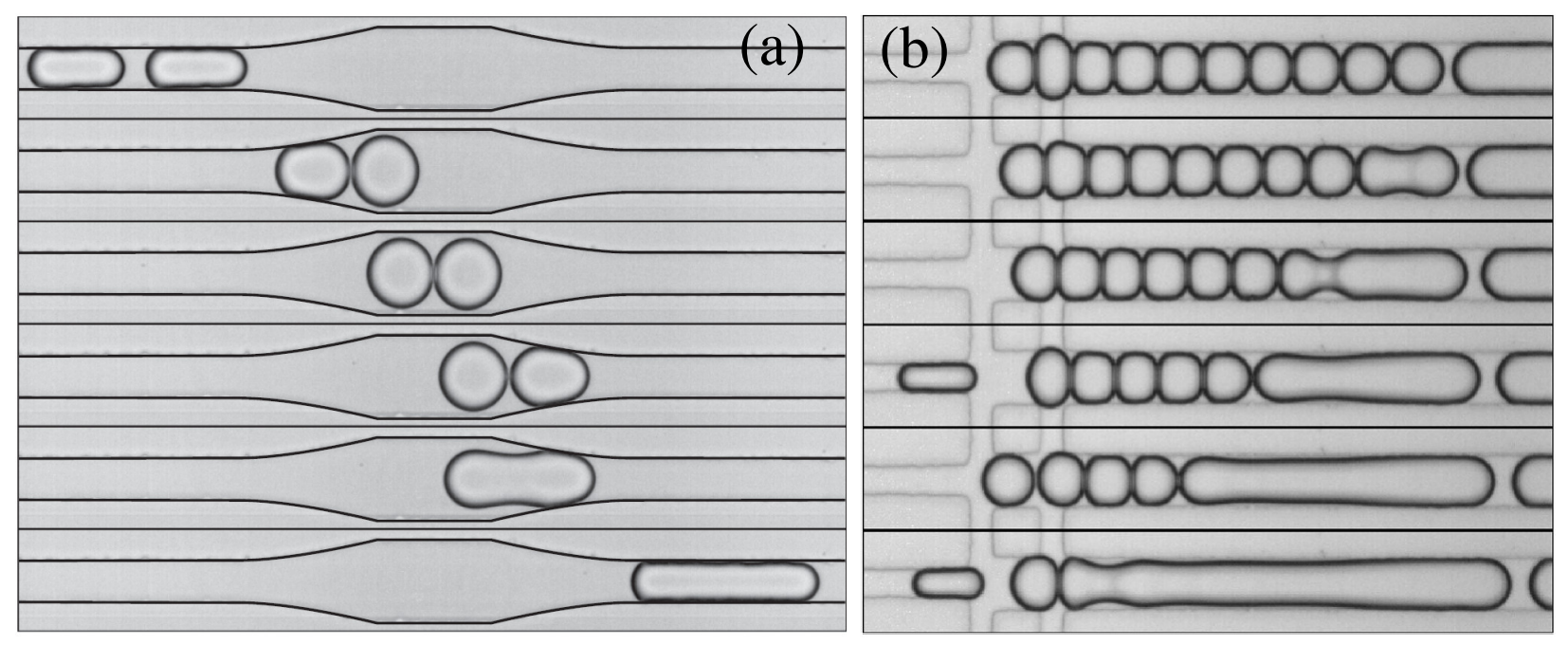

Figure 9 Quantitative analysis of droplet coalescence in microfluidic channels. The separation of droplets can induce the coalescence (a). In a stream of droplets, a first coalescence will force the separation of the next interface. This separation leads to a second coalescence and then to collective coalescence by the cascade of successive separations/coalescence events (b). Figure reprinted with permission from Bremond et al., PRL, 100, 024501, 2008. Copyright (2008) by the American Physical Society ${ }^{64}$

where the fusion of droplets has to be controlled, it is possible to use this dynamic process for a passive control of the coalescence of droplet pairs ${ }^{104}$. This system complements several other passive systems developed for the control droplets coalescence, for example based on wetting patches $95,150,151$. Applications, however, often require an active control of the coalescence.

A stable interface covered by surfactants can be destabilized in controlled manner in electric fields. Electrocoalescence consists in the destabilization of the thin oil film between two aqueous droplets $^{30}$. By the control of single oil lamelae between two droplets, it has been shown that the destabilization of the oil layer is linked to an electro-hydrodynamic instability of the oil film and is not induced by a dielectric breakdown of the insulating oil ${ }^{63}$. Collective behavior can also be observed with propagation of coalescence events ${ }^{76,96}$ leading to destabilization of large parts of an emulsion. The principle of electrocoalescence has been used to trigger the fusion of droplet for the study and control of very fast reactions ${ }^{31,101,152,153}$ or to perform several bio-chemical reactions in series ${ }^{104}$. Electric field can also be used to tune the adhesion properties of surfactant bilayers $^{86}$ and direct measurement of the electrical properties of lipid bilayers have also been recently performed ${ }^{79}$. Reciprocally, the fine control of the adhesion properties of droplets and 
a microfluidic control of those droplets in microfluidics allows quantitative measurement of the behavior of the formed lipid bilayers in electric fields, providing insights to a better understanding of electroporation processes ${ }^{154}$. The electric fields generated on chip are therefore versatile tools to control interfacial layers and can be used to modulate the energetic barrier linked to the surfactant at interfaces. In general, microfluidic devices provide new methods to quantitatively analyse dynamic interfacial phenomena.

\section{Surface tension measurement and interfacial rheology}

Understanding coalescence also requires a better understanding of the dynamics of surfactant-laden interfaces. As discussed, the coalescence mechanism is linked to the dynamics of the surfactant layers ${ }^{17}$. It becomes then crucial to determine the rheological properties of the interface: how does the surfactant flow at the interface as a function of the applied external shear stress ? What is the boundary condition at the interface? These questions can be answered by interfacial rheology methods $14,144,155,156$. However, once again, it is extremely difficult to obtain informations on the interfacial properties at the time and length scales reached in microfluidic applications ${ }^{144}$. The study in microfluidic of these quantities is therefore extremely interesting. The possibility to perform micro Particle Image Velocimetry (microPIV) measurements of the droplet flow ${ }^{91}$ provides informations on the boundary conditions at the interface which is linked to the way surfactant are flowing. Coupling these microPIV informations with in situ measurements of droplet deformations provides means to extract more information on the rheological properties of interfaces ${ }^{84,157-159}$.

Surface tension measurement are feasible in microfluidics: using electrowetting surface tension in oil have been measured with droplet sizes down to $20 \mathrm{~nL}^{160}$. In microfluidic channels, the effect of surfactant on surface tension is also measurable. As already discussed, surfactant is not fully covering the droplet interface right after droplet production ${ }^{111}$. The surface tension of the interface is then comprised between the surface tension without surfactant and the equilibrium surface tension in the presence of surfactant. The surface tension being one of the parameter controlling droplet size in a T-junction or in a flow focusing junction, a measurement of droplet size 
is an indirect way to access the surface tension at the time-scale of droplet production ${ }^{81,82}$. More complex dynamic processes such as tip-streaming ${ }^{83,161}$ which is an instability of the surfactant layer in an external flow field or other interfacial instabilities at low surface tensions ${ }^{71}$ can also be addressed in microfluidic environments. Microfluidic systems are therefore now also used to access informations on surface tension at small scales and with dynamics much below $1 \mathrm{~s}^{162}$. They offer a versatile platform for the study of dynamic processes at short length-scale in a well controlled environment and should provide new insights into the dynamics of interfaces ${ }^{14}$.

\section{Active and reactive surfactants: Towards complex systems}

Finally, recent systems have been described to actively control the interfacial properties of surfactants. The aggregation of droplets - and therefore their adhesion properties - can be controlled by external stimuli such as $\mathrm{pH}$ variations in the continuous phase ${ }^{163}$. This aggregation is reversible and could be used to control self-organization in emulsion. In microfluidic channels the addition of chemicals such as EDTA or salt has been shown to influence droplet stability against coalescence or the adhesion properties of the droplets in a reversible manner ${ }^{164}$. Such systems could represent interesting opportunities as environmental sensors in liquid systems. Droplet interfaces can be used to display catalytic parts for chemical reactions and organic synthesis ${ }^{165}$. In such cases, the increase of surface area per unit of volume coming from the reaction in emulsion is beneficial. The possibility for surfactants to react with other components of the systems also provides new actuation mechanisms. Indeed it is well known that surface tension gradients can induce a liquid flow through Marangoni force ${ }^{166}$. When two surfactants are mixed at the surface of a droplet with an heterogeneous distribution of the molecule, the droplet can also move. In the presence of a dynamic exchange of the surfactant at the interface and a chemical reaction which switches the interfacial properties of the surfactant, the motion can be sustained for a few minutes and the speed of the droplet can be controlled by the concentration of the surfactant ${ }^{167}$. In a population of monodisperse droplets, collective dynamics can then be observed, similar to the collective motion that can happen in ensemble of micro-organisms. A combination of reactive surfactants ${ }^{79}$, environ- 
mental sensing surfactants ${ }^{163}$, surfactant-induced locomotion ${ }^{166,167}$, and communication between agents (here the droplets) through chemical signaling ${ }^{20,167}$ should provide means to produce, in the future, powerful biomimetic systems for applications as biosensors, autonomous microsystems or programmable microcontrollers for soft-matter. 


\section{Conclusions and outlook}

Surfactants are an essential part of the droplet-based microfluidic technology. They are involved in the stabilization of droplet interfaces, in the biocompatibility of the system and in the exchange rate of molecules between droplets. The recent progress in the applications of droplet-based microfluidics have been possible by the development of new molecules and their charaterisations either off-chip or on-chip. Fluorosurfactants for water in fluorinated oil emulsions are very interesting systems for biotechnology applications. They can be used as systems for thermocycling, cell encapsulation and proliferation and are therefore the most promising system for the miniaturization of biochemical assays in micron-sized emulsion droplets. The use of such micron sized droplets and their actuation at time-scale of the order of a millisecond in microchannels requires the characterisation of surfactants at these time and length-scales. In this respect, microfluidic systems appear to be very powerful tools to study surfactant dynamics at the time- and length- scale relevant for the corresponding microfluidic applications. Finally, the control of interfaces in droplet-based microfluidics offers means to produce new materials in a very controlled maner. Reactions can be performed in droplets but also at interfaces for the synthesis of core-shell particles ${ }^{168}$ or polymerosomes ${ }^{169}$. Double and multiple emulsions can also be produced ${ }^{98,170}$. In such systems, surfactants are essential since the interfacial properties of the different phases will determine whether or not multiple emulsions can be stably generated ${ }^{171}$. Highly complex systems - including for example oscillating chemical reactions - can be studied and controlled in microfluidics. The capability of microfluidics to generate controlled liquid structures with complex functionalities at interfaces, in the continuous phase, or in the dispersed phase, should bring this technology towards the creation

of autonomous, biomimetic microsystems that could be used as model systems of micro-organisms or to programmable microcontroller for soft-matter. 


\section{Acknowledgments}

The author thanks Dr. J. Brian Hutchison (Raindance Technologies), Dr. Valérie Taly (ISIS-UdSCNRS) and Dr. S. Vessigaud for helpful comments as well as Prof. Dr. Stephan Herminghaus (MPI-ds Goettingen) for his support and Dr. E. Rio (Universit Paris Sud) for helpful discussions. Financial support from the Max-Planck Gesellschaft and from the Deutsche Forschunggemeinschaft through the Sonderforschungbereich 755 (Nanoscale Photonic Imaging) are also acknowledged.

\section{References}

[1] T. Thorsen, R. W. Roberts, F. H. Arnold and S. R. Quake, Phys. Rev. Lett., 2001, 86, 4163-4166.

[2] C. M. Dobson, G. B. Ellison, A. F. Tuck and V. Vaida, Proc. Natl. Acad. Sci. U. S. A., 2000, 97, 11864-11868.

[3] A. D. Griffiths and D. S. Tawfik, Trends Biotechnol., 2006, 24, 395-402.

[4] B. T. Kelly, J.-C. Baret, V. Taly and A. D. Griffiths, Chem. Commun., 2007, 1773-1788.

[5] S.-Y. Teh, R. Lin, L.-H. Hung and A. P. Lee, Lab Chip, 2008, 8, 198-220.

[6] J.-C. Baret, V. Taly, M. Ryckelynck, C. A. Merten and A. D. Griffiths, Med. Sci., 2009, 25, 627-632.

[7] A. Huebner, S. Sharma, M. Srisa-Art, F. Hollfelder, J. B. Edel and A. J. Demello, Lab Chip, 2008, 8, $1244-$ 1254.

[8] A. B. Theberge, F. Courtois, Y. Schaerli, M. Fischlechner, C. Abell, F. Hollfelder and W. T. S. Huck, Angew. Chem., Int. Ed., 2010, 49, 5846-5868.

[9] B. Kintses, L. D. van Vliet, S. R. A. Devenish and F. Hollfelder, Curr. Opin. Chem. Biol., 2010, 14, 548-555.

[10] M. J. Rosen, in Surfactants and Interfacial phenomena, John Wiley \& Sons, Inc., 2004, pp. i-xiii.

[11] B. Cabane and S. Henon, Liquides: Solutions, dispersions, emulsions, gels, Belin, 2003.

[12] C. Ybert and J.-M. di Meglio, Eur. Phys. J. B., 1998, 4, 313-319.

[13] E. Guyon, J. Hulin, L. Petit and C. Mitescu, Physical Hydrodynamics, Oxford University Press, 2010. 
[14] P. Erni, Soft Matter, 2011, 7, 7586-7600.

[15] J. Bibette, F. Leal-Calderon and P. Poulin, Rep. Prog. Phys., 1999, 62, 696-1033.

[16] J. Bibette, D. Morse, T. Witten and D. Weitz, Phys. Rev. Lett., 1992, 69, 2439-2442.

[17] B. Dai and L. Leal, Physics of fluids, 2008, 20, 040802.

[18] P. Taylor, Colloids and Surfaces A: Physicochemical and Engineering Aspects, 1995, 99, 175-185.

[19] H. N. Joensson, M. Uhln and H. A. Svahn, Lab Chip, 2011, 11, 1305-1310.

[20] Y. Bai, X. He, D. Liu, S. N. Patil, D. Bratton, A. Huebner, F. Hollfelder, C. Abell and W. T. S. Huck, Lab Chip, 2010, 10, 1281-1285.

[21] Y. N. Ahn, A. Gupta, A. Chauhan and D. I. Kopelevich, Langmuir, 2011.

[22] S. Ariyaprakai and S. R. Dungan, J. Colloid Interface Sci., 2010, 343, 102-108.

[23] S. L. Anna, N. Bontoux and H. A. Stone, Appl. Phys. Lett., 2003, 82, 364-366.

[24] C. Priest, S. Herminghaus and R. Seemann, Appl. Phys. Lett., 2006, 88, 024106-3.

[25] D. R. Link, S. L. Anna, D. A. Weitz and H. A. Stone, Phys. Rev. Lett., 2004, 92, 054503.

[26] A. R. Abate and D. A. Weitz, Lab Chip, 2011, 11, 1911-1915.

[27] J.-C. Baret, O. J. Miller, V. Taly, M. Ryckelynck, A. El-Harrak, L. Frenz, C. Rick, M. L. Samuels, J. B. Hutchison, J. J. Agresti, D. R. Link, D. A. Weitz and A. D. Griffiths, Lab Chip, 2009, 9, 1850-1858.

[28] L. Frenz, K. Blank, E. Brouzes and A. D. Griffiths, Lab Chip, 2009, 9, 1344-1348.

[29] P. Mary, A. R. Abate, J. J. Agresti and D. A. Weitz, Biomicrofluidics, 2011, 5, 24101.

[30] M. Chabert, K. D. Dorfman and J. L. Viovy, Electrophoresis, 2005, 26, 3706-3715.

[31] K. Ahn, J. Agresti, H. Chong, M. Marquez and D. A. Weitz, Appl. Phys. Lett., 2006, 88, 264105.

[32] K. Ahn, C. Kerbage, T. P. Hunt, R. M. Westervelt, D. R. Link and D. A. Weitz, Appl. Phys. Lett., 2006, 88, 024104.

[33] L. M. Fidalgo, G. Whyte, D. Bratton, C. F. Kaminski, C. Abell and W. T. S. Huck, Angew. Chem., Int. Ed., 2008, 47, 2042-2045. 
[34] J. J. Agresti, E. Antipov, A. R. Abate, K. Ahn, A. C. Rowat, J.-C. Baret, M. Marquez, A. M. Klibanov, A. D. Griffiths and D. A. Weitz, Proc. Natl. Acad. Sci. U. S. A., 2010, 107, 4004-4009.

[35] B. Zheng and R. F. Ismagilov, Angew. Chem., Int. Ed., 2005, 44, 2520-2523.

[36] E. Brouzes, M. Medkova, N. Savenelli, D. Marran, M. Twardowski, J. B. Hutchison, J. M. Rothberg, D. R. Link, N. Perrimon and M. L. Samuels, Proc. Natl. Acad. Sci. U. S. A., 2009, 106, 14195-14200.

[37] J.-C. Baret, Y. Beck, I. Billas-Massobrio, D. Moras and A. D. Griffiths, Chem. Biol., 2010, 17, 528-536.

[38] R. Williams, S. G. Peisajovich, O. J. Miller, S. Magdassi, D. S. Tawfik and A. D. Griffiths, Nat. Methods, 2006, 3, 545-550.

[39] O. J. Miller, K. Bernath, J. J. Agresti, G. Amitai, B. T. Kelly, E. Mastrobattista, V. Taly, S. Magdassi, D. S. Tawfik and A. D. Griffiths, Nat. Methods, 2006, 3, 561-570.

[40] N. R. Beer, B. J. Hindson, E. K. Wheeler, S. B. Hall, K. A. Rose, I. M. Kennedy and B. W. Colston, Anal. Chem., 2007, 79, 8471-8475.

[41] L. Mazutis, J.-C. Baret, P. Treacy, Y. Skhiri, A. F. Araghi, M. Ryckelynck, V. Taly and A. D. Griffiths, Lab Chip, 2009, 9, 2902-2908.

[42] D. Pekin, Y. Skhiri, J.-C. Baret, D. L. Corre, L. Mazutis, C. B. Salem, F. Millot, A. E. Harrak, J. B. Hutchison, J. W. Larson, D. R. Link, P. Laurent-Puig, A. D. Griffiths and V. Taly, Lab Chip, 2011, 11, 2156 - 2166.

[43] Q. Zhong, S. Bhattacharya, S. Kotsopoulos, J. Olson, V. Taly, A. D. Griffiths, D. R. Link and J. W. Larson, Lab Chip, 2011.

[44] L. S. Roach, H. Song and R. F. Ismagilov, Anal. Chem., 2005, 77, 785-796.

[45] A. Lee, S. Tang, C. Mace and G. Whitesides, Langmuir, 2011, DOI:10.1021/la201832d.

[46] C. Zhang and D. Xing, Chem Rev, 2010, 110, 4910-4947.

[47] M. Margulies, M. Egholm, W. E. Altman, S. Attiya, J. S. Bader, L. A. Bemben, J. Berka, M. S. Braverman, Y.-J. Chen, Z. Chen, S. B. Dewell, L. Du, J. M. Fierro, X. V. Gomes, B. C. Godwin, W. He, S. Helgesen, C. H. Ho, C. H. Ho, G. P. Irzyk, S. C. Jando, M. L. I. Alenquer, T. P. Jarvie, K. B. Jirage, J.-B. Kim, J. R. Knight, J. R. Lanza, J. H. Leamon, S. M. Lefkowitz, M. Lei, J. Li, K. L. Lohman, H. Lu, V. B. Makhijani, K. E. McDade, M. P. McKenna, E. W. Myers, E. Nickerson, J. R. Nobile, R. Plant, B. P. Puc, M. T. Ronan, G. T. Roth, G. J. 
Sarkis, J. F. Simons, J. W. Simpson, M. Srinivasan, K. R. Tartaro, A. Tomasz, K. A. Vogt, G. A. Volkmer, S. H. Wang, Y. Wang, M. P. Weiner, P. Yu, R. F. Begley and J. M. Rothberg, Nature, 2005, 437, 376-380.

[48] P. Kumaresan, C. J. Yang, S. A. Cronier, R. G. Blazej and R. A. Mathies, Anal. Chem., 2008, 80, 3522-3529.

[49] Y. Zeng, R. Novak, J. Shuga, M. T. Smith and R. A. Mathies, Anal. Chem., 2010, 82, 3183-3190.

[50] Y. N. Xia and G. M. Whitesides, Annu. Rev. Mater. Sci., 1998, 28, 153-184.

[51] X. Leng, W. Zhang, C. Wang, L. Cui and C. J. Yang, Lab Chip, 2010, 10, 2841-2843.

[52] Y. Schaerli, V. Stein, M. M. Spiering, S. J. Benkovic, C. Abell and F. Hollfelder, Nucleic Acids Res., 2010, 38, e201.

[53] P. Mary, L. Dauphinot, N. Bois, M.-C. Potier, V. Studer and P. Tabeling, Biomicrofluidics, 2011, 5, 024109.

[54] B. M. Paegel and G. F. Joyce, Chem. Biol., 2010, 17, 717-724.

[55] F. J. Ghadessy, J. L. Ong and P. Holliger, Proc. Natl. Acad. Sci. U. S. A., 2001, 98, 4552-4557.

[56] M. M. Kiss, L. Ortoleva-Donnelly, N. R. Beer, J. Warner, C. G. Bailey, B. W. Colston, J. M. Rothberg, D. R. Link and J. H. Leamon, Anal. Chem., 2008, 80, 8975-8981.

[57] P. Umbanhowar, V. Prasad and D. Weitz, Langmuir, 2000, 16, 347-341.

[58] V. Trivedi, A. Doshi, G. K. Kurup, E. Ereifej, P. J. Vandevord and A. S. Basu, Lab Chip, 2010, 10, $2433-2442$.

[59] G. Cristobal, L. Arbouet, F. Sarrazin, D. Talaga, J.-L. Bruneel, M. Joanicot and L. Servant, Lab Chip, 2006, 6, 1140-1146.

[60] L. Yobas, S. Martens, W.-L. Ong and N. Ranganathan, Lab Chip, 2006, 6, 1073-1079.

[61] L. Shui, A. van den Berg and J. C. T. Eijkel, Lab Chip, 2009, 9, 795-801.

[62] P. S. Dittrich, M. Jahnz and P. Schwille, Chembiochem, 2005, 6, 811-814.

[63] C. Priest, S. Herminghaus and R. Seemann, Appl. Phys. Lett., 2006, 89, 134101-3.

[64] N. Bremond, A. R. Thiam and J. Bibette, Phys. Rev. Lett., 2008, 1, 024501.

[65] N. Bremond, H. Domejean and J. Bibette, Phys. Rev. Lett., 2011, 214502.

[66] H. Willaime, V. Barbier, L. Kloul, S. Maine and P. Tabeling, Phys. Rev. Lett., 2006, 96, 054501. 
[67] T. Beatus, T. Tlusty and R. Bar-Ziv, Nature Physics, 2006, 2, 743-748.

[68] V. Chokkalingam, S. Herminghaus and R. Seemann, Appl. Phys. Lett., 2008, 93, 254101-3.

[69] L. Menetrier-Deremble and P. Tabeling, Phys. Rev. E Stat. Nonlin. Soft Matter Phys., 2006, 74, 035303.

[70] M. Toiya, V. K. Vanag and I. R. Epstein, Angew. Chem., Int. Ed., 2008, 47, 7753-7755.

[71] M. Hashimoto, P. Garstecki, H. A. Stone and G. M. Whitesides, Soft Matter, 2008, 4, 1403-1413.

[72] M. Chabert and J.-L. Viovy, Proc. Natl. Acad. Sci. U. S. A., 2008, 105, 3191-3196.

[73] E. Um, S.-G. Lee and H. J-Y Park, Appl. Phys. Lett., 2010, 97, 153703.

[74] C. N. Baroud, M. R. de Saint Vincent and J.-P. Delville, Lab Chip, 2007, 7, 1029-1033.

[75] A. M. Huebner, C. Abell, W. T. S. Huck, C. N. Baroud and F. Hollfelder, Anal. Chem., 2011, 83, 1462-1468.

[76] A. R. Thiam, N. Bremond and J. Bibette, Phys. Rev. Lett., 2009, 102, 188304.

[77] H. Kim, D. Luo, D. Link, D. Weitz, M. Marquez and Z. Cheng, Appl. Phys. Lett., 2007, 91, 133106.

[78] F. Malloggi, H. Gu, A. G. Banpurkar, S. A. Vanapalli and F. Mugele, Eur. Phys. J. E Soft Matter, 2008, 26, 91-96.

[79] S. Thutupalli, S. Herminghaus and R. Seemann, Soft Matter, 2010.

[80] T. Ward, M. Faivre and H. Stone, Langmuir, 2010, 26, 9233-9239.

[81] K. Wang, Y. Lu, J. Xu and G. Luo, Langmuir, 2009, 25, 2153-2158.

[82] M. L. J. Steegmans, A. Warmerdam, K. G. P. H. Schron and R. M. Boom, Langmuir, 2009, 25, 9751-9758.

[83] S. L. Anna and H. C. Mayer, Physics of fluids, 2006, 18, 121512.

[84] J. D. Martin and S. D. Hudson, New Journal of Physics, 2009, 11, 115005.

[85] A. Hatch, J. Fisher, S. Pentoney, D. Yang and A. Lee, Lab Chip, 2011, 11, 2509-2517.

[86] S. Punnamaraju and A. J. Steckl, Langmuir, 2011, 27, 618-626.

[87] S. A. Vanapalli, A. G. Banpurkar, D. van den Ende, M. H. G. Duits and F. Mugele, Lab Chip, 2009, 9, 982-990.

[88] M. Belloul, W. Engl, A. Colin, P. Panizza and A. Ajdari, Phys. Rev. Lett., 2009, 102, 194502. 
[89] H. Song and R. F. Ismagilov, J. Am. Chem. Soc., 2003, 125, 14613-14619.

[90] H. Song, J. D. Tice and R. F. Ismagilov, Angew. Chem., Int. Ed., 2003, 42, 768-772.

[91] C. King, E. Walsh and R. Grimes, Microfluidics Nanofluidics, 2007, 3, 463-472.

[92] B. Zheng, C. J. Gerdts and R. F. Ismagilov, Curr. Opin. Struct. Biol., 2005, 15, 548-555.

[93] B. Zheng, J. D. Tice and R. F. Ismagilov, Anal. Chem., 2004, 76, 4977-4982.

[94] M. Chabert, K. D. Dorfman, P. de Cremoux, J. Roeraade and J.-L. Viovy, Anal. Chem., 2006, 78, 7722-7728.

[95] D. Chen, W. Du, Y. Liu, W. Liu, A. Kuznetsov, F. E. Mendez, L. H. Philipson and R. F. Ismagilov, Proc. Natl. Acad. Sci. U. S. A., 2008, 105, 16843-16848.

[96] M. Zagnoni, G. L. Lain and J. M. Cooper, Langmuir, 2010, 26, 14443-14449.

[97] E. Schonbrun, A. R. Abate, P. E. Steinvurzel, D. A. Weitz and K. B. Crozier, Lab Chip, 2010, 10, 852-856.

[98] A. R. Abate and D. A. Weitz, Small, 2009, 5, 2030-2032.

[99] J. Clausell-Tormos, D. Lieber, J.-C. Baret, A. El-Harrak, O. J. Miller, L. Frenz, J. Blouwolff, K. J. Humphry, S. Koester, H. Duan, C. Holtze, D. A. Weitz, A. D. Griffiths and C. A. Merten, Chem. Biol., 2008, 15, 427-437.

[100] L. Frenz, J. Blouwolff, A. D. Griffiths and J.-C. Baret, Langmuir, 2008, 24, 12073-12076.

[101] L. Frenz, A. E. Harrak, M. Pauly, S. Bgin-Colin, A. D. Griffiths and J.-C. Baret, Angew. Chem., Int. Ed., 2008, 47, 6817-6820.

[102] A. R. Abate, T. Hung, P. Mary, J. J. Agresti and D. A. Weitz, Proc. Natl. Acad. Sci. U. S. A., 2010, 107, 19163-19166.

[103] C. H. J. Schmitz, A. C. Rowat, S. Koester and D. A. Weitz, Lab Chip, 2009, 9, 44-49.

[104] L. Mazutis, J.-C. Baret and A. D. Griffiths, Lab Chip, 2009, 9, 2665-2672.

[105] L. Mazutis, A. F. Araghi, O. J. Miller, J.-C. Baret, L. Frenz, A. Janoshazi, V. Taly, B. J. Miller, J. B. Hutchison, D. Link, A. D. Griffiths and M. Ryckelynck, Anal. Chem., 2009, 81, 4813-4821.

[106] A. B. Theberge, G. Whyte and W. T. S. Huck, Anal. Chem., 2010, 82, 3449-3453.

[107] L. Granieri, J.-C. Baret, A. D. Griffiths and C. A. Merten, Chem. Biol., 2010, 17, 229-235. 
[108] L. Mazutis and A. Griffiths, Appl. Phys. Lett., 2009, 95, 204103.

[109] P. Abbyad, P.-L. Tharaux, J.-L. Martin, C. N. Baroud and A. Alexandrou, Lab Chip, 2010.

[110] P. Marcoux, M. Dupoy, R. Mathey, A. Novelli-Rousseau, V. Heran, S. Morales, F. Rivera, P. Joly, J. Moy and F. Mallard, Colloids and surfaces A - Physicochemical and engineering aspects, 2011, 377, 54-62.

[111] J.-C. Baret, F. Kleinschmidt, A. E. Harrak and A. D. Griffiths, Langmuir, 2009, 25, 6088-6093.

[112] D. J. Holt, R. J. Payne, W. Y. Chow and C. Abell, J. Colloid Interface Sci., 2010.

[113] D. J. Holt, R. J. Payne, W. Y. Chow and C. Abell, J. Colloid Interface Sci., 2010, 350, $205-211$.

[114] J. Q. Boedicker, L. Li, T. R. Kline and R. F. Ismagilov, Lab Chip, 2008, 8, 1265-1272.

[115] I. Giaever and C. R. Keese, Proc. Natl. Acad. Sci. U. S. A., 1983, 80, 219-222.

[116] C. R. Keese and I. Giaever, Science, 1983, 219, 1448-1449.

[117] C. R. Keese and I. Giaever, Proc. Natl. Acad. Sci. U. S. A., 1983, 80, 5622-5626.

[118] D. M. Lemal, J. Org. Chem., 2004, 69, 1-11.

[119] J. G. Riess, J. L. Dalfors, G. K. Hanna, D. H. Klein, M. P. Krafft, T. J. Pelura and E. G. Schutt, Biomater. Artif. Cells Immobilization Biotechnol., 1992, 20, 839-842.

[120] M. P. Krafft, M. Postel, J. G. Riess, Y. Ni, T. J. Pelura, G. K. Hanna and D. Song, Biomater. Artif. Cells Immobilization Biotechnol., 1992, 20, 865-868.

[121] J. G. Riess and M. P. Krafft, Artif. Cells Blood Substit. Immobil. Biotechnol., 1997, 25, 43-52.

[122] J. G. Riess and M. P. Krafft, Biomaterials, 1998, 19, 1529-1539.

[123] P. Abbyad, R. Dangla, A. Alexandrou and C. N. Baroud, Lab Chip, 2011, 11, 813-821.

[124] K. P. Johnston, K. Harrison, M. Clarke, S. Howdle, M. Heitz, F. Bright, C. Carlier and T. W. Randolph, Science, 1996, 271, 624 .

[125] K. P. Johnston, T. Randolph, F. Bright and S. Howdle, Science, 1996, 272, 1726 b.

[126] V. Sadtler, F. Jeanneaux, M. Krafft, J. Rabai and J. Riess, New Journal of Chemistry, 1998, 609-613. 
[127] H. M. Courrier, F. Pons, J. M. Lessinger, N. Frossard, M. P. Krafft and T. F. Vandamme, Int. J. Pharm., 2004, 282, 131-140.

[128] H. Nakahara, S. Lee, M. P. Krafft and O. Shibata, Langmuir, 2010, 26, 18256-18265.

[129] C. Holtze, A. C. Rowat, J. J. Agresti, J. B. Hutchison, F. E. Angile, C. H. J. Schmitz, S. Koester, H. Duan, K. J. Humphry, R. A. Scanga, J. S. Johnson, D. Pisignano and D. A. Weitz, Lab Chip, 2008, 8, 1632-1639.

[130] WO/2008/021123A1, Fluorocarbon emulsion stabilizing surfactants, 2008.

[131] S. Koester, F. E. Angil, H. Duan, J. J. Agresti, A. Wintner, C. Schmitz, A. C. Rowat, C. A. Merten, D. Pisignano, A. D. Griffiths and D. A. Weitz, Lab Chip, 2008, 8, 1110-1115.

[132] A. Aharoni, G. Amitai, K. Bernath, S. Magdassi and D. S. Tawfik, Chem. Biol., 2005, 12, 1281-1289.

[133] N. Chidambaram and D. J. Burgess, AAPS PharmSci., 2000, 2, E30.

[134] N. Chidambaram and D. J. Burgess, AAPS PharmSci., 2000, 2, E28.

[135] K. A. Yoon and D. J. Burgess, Pharm. Res., 1996, 13, 433-439.

[136] G. Woronoff, A. E. Harrak, E. Mayot, O. Schicke, O. J. Miller, P. Soumillion, A. D. Griffiths and M. Ryckelynck, Anal. Chem., 2011, 83, 2852-2857.

[137] P. Fletcher, A. Howe and B. Robinson, J. Chem. Soc., Faraday Trans. 1, 1987, 83, 985-1006.

[138] A. V. Pietrini and P. L. Luisi, Chembiochem, 2004, 5, 1055-1062.

[139] R. Pashley, J. Phys. Chem. B, 2003, 107, 1714-1720.

[140] B. Neumann, B. Vincent, R. Krustev and H.-J. Mller, Langmuir, 2004, 20, 4336-4344.

[141] J. Eastoe and C. Ellis, Adv. Colloid. Interface Sci., 2007, 134-135, 89-95.

[142] R. Follana, D. Klein, M. P. Krafft, D. M. Long, C. D. Long, Y. Ni, J. G. Riess and A. Valla, Biomater. Artif. Cells Immobilization Biotechnol, 1992, 20, 1059-1061.

[143] D. M. Colegate and C. D. Bain, Phys. Rev. Lett., 2005, 95, 198302.

[144] S. Derkach, J. Kraegel and R. Miller, Colloid Journal, 2009, 71, 1-17.

[145] F. Jin, R. Balasubramaniam and K. Stebe, The journal of adhesion, 2004, 80, 773-796. 
[146] Y. C. Tan, Y. L. Ho and A. P. Lee, Microfluidics Nanofluidics, 2007, 3, 495-499.

[147] G. F. Christopher, J. Bergstein, N. B. End, M. Poon, C. Nguyen and S. L. Anna, Lab Chip, 2009, 9, 1102-1109.

[148] A. Lai, N. Bremond and H. Stone, J. Fluid. Mechanics, 2009, 623, 97-107.

[149] H. Chen, Y. Zhao, J. Li, M. Guo, J. Wan, D. Weitz and H. Stone, Lab Chip, 2011, 11, 2312-2315.

[150] L. M. Fidalgo, C. Abell and W. T. S. Huck, Lab Chip, 2007, 7, 984-986.

[151] Y. Liu and R. F. Ismagilov, Langmuir, 2009, 25, 2854-2859.

[152] V. Chokkalingam, B. Weidenhof, M. Krmer, S. Herminghaus, R. Seemann and W. F. Maier, Chemphyschem, 2010, 11, 2091-2095.

[153] V. Chokkalingam, B. Weidenhof, M. Krmer, W. F. Maier, S. Herminghaus and R. Seemann, Lab Chip, 2010, 10, 1700-1705.

[154] A. R. Thiam, N. Bremond and J. Bibette, Phys. Rev. Lett., 2011, 107, 068301.

[155] D. Langevin, Current opinion in colloid and Interface science, 1998, 3, 600-607.

[156] J. Kraegel and S. Derkatch, Current opinion in colloid and interface science, 2010, 15, 246-255.

[157] S. D. Hudson, J. T. Cabral, W. J. Goodrum, K. L. Beers and E. J. Amis, Appl. Phys. Lett., 2005, 87, 081905.

[158] J. T. Cabral and S. D. Hudson, Lab Chip, 2006, 6, 427-436.

[159] J. Martin, J. Marhefka, K. Migler and S. Hudson, Adv. Mater., 2011, 23, 426-432.

[160] A. G. Banpurkar, K. P. Nichols and F. Mugele, Langmuir, 2008, 24, 10549-10551.

[161] W. Lee, L. walker and S. Anna, Macromol. Mater. Eng., 2011, 296, 203-213.

[162] N. J. Alvarez, L. M. Walker and S. L. Anna, Langmuir, 2010, 26, 13310-13319.

[163] W. Bauer, J. Kotar, P. Cicuta, R. Woodward, J. Weaver and W. T. S. WTS Huck, Soft Matter, 2011, 7, 42144220.

[164] A. S. Malcolm, A. F. Dexter, J. A. Katakdhond, S. I. Karakashev, A. V. Nguyen and A. P. J. Middelberg, Chemphyschem, 2009, 10, 778-781. 
[165] A. B. Theberge, G. Whyte, M. Frenzel, L. M. Fidalgo, R. C. R. Wootton and W. T. S. Huck, Chem. Commun., $2009,6225-6227$.

[166] H. Haidara, L. Vonna and J. Schultz, J. Chem. Phys., 1997, 107, 630-637.

[167] S. Thutupalli, R. Seemann and S. Herminghaus, New Journal of Physics, 2011, 7, 013021.

[168] Y. Hennequin, N. Pannacci, C. P. de Torres, G. Tetradis-Meris, S. Chapuliot, E. Bouchaud and P. Tabeling, Langmuir, 2009, 25, 7857-7861.

[169] E. Lorenceau, A. S. Utada, D. R. Link, G. Cristobal, M. Joanicot and D. A. Weitz, Langmuir, 2005, 21, 91839186.

[170] S. Okushima, T. Nisisako, T. Torii and T. Higuchi, Langmuir, 2004, 20, 9905-9908.

[171] N. Pannacci, H. Bruus, D. Bartolo, I. Etchart, T. Lockhart, Y. Hennequin, H. Willaime and P. Tabeling, Phys. Rev. Lett., 2008, 101, 164502. 